In summary, for patients we can obtain a more approxinate value for $L D L-C$ that, when the serum concentrations if TG are $>3.3 \mathrm{mmol} / \mathrm{L}$, is almost surely overestimated. Only those with an estimated LDL-C $>4.1 \mathrm{mmol} / \mathrm{L}$, espeially if their serum TG is $<3.3 \mathrm{mmol} / \mathrm{L}$, will merit addiional investigation. This proposed approach is summaized in Figure 2.

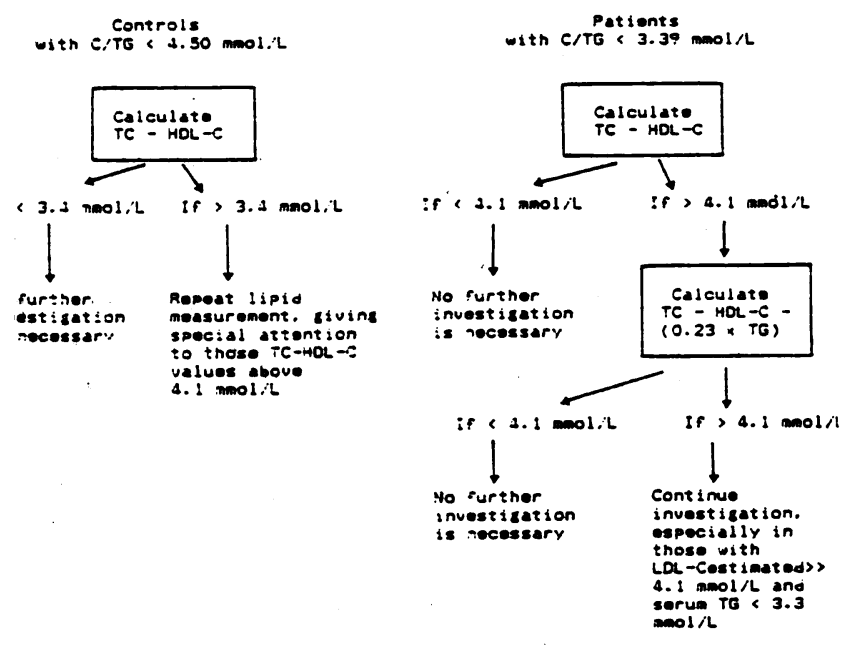

iig. 2. Strategy proposed to determine if further investigation is lecessary among those individuals having a possibly unreliable alculated LDL-C
We are grateful for the financial support of the Autonomous Government of the Canary Islands, Spain.

\section{References}

1. Friedewald WT, Levy RI, Fredrickson DS. Estimation of the concentration of low-density lipoprotein cholesterol in plasma, without use of the preparative ultracentrifuge. Clin Chem 1972;18:499-502.

2. De Long DM, De Long ER, Wood DD, Lippel K, Rifkind BM. A comparison of the methods for the estimation of plasma low and very low density lipoprotein cholesterol. The LRC prevalence study. J Am Med Assoc 1986;265:2372-7.

3. Elefson RD. Variability in the VLDL cholesterolVLDL triglycerides ratio and related errors in the estimation of $\mathrm{LDL}$ cholesterol [Abstract]. Clin Chem 1985;31:948.

4. Rao A, Parker AH, El-Sheroni NA, Babelly MM. Calculation of low-density lipoprotein cholesterol with use of triglyceride/cholesterol ratios in lipoproteins compared with other calculation methods. Clin Chem 1988;34:2532-4.

5. Marsal A, Gómez-Gerique JA, Franco Peral M. Validación de la formula de Friedewald [Communication]. Clin Invest Arteriosclerosis 1989;1(Suppl 1):16.

6. Siedel J, Haegele EO, Ziegenhorn J, Wahlefeld AW. Reagent for the enzymic determination of serum total cholesterol with improved lipolytic efficiency. Clin Chem 1983;29:1075-80.

7. Wahlefeld AW. Triglycerides determination after enzymatic hydrolysis. In: Bergmeyer HU, ed. Methods of enzyme analysis, 2nd ed. New York: Verlag Chemie-Academic Press, 1974:1824-31. 8. Lopes-Virella MF, Stone P, Ellis S, Colwell JA. Cholesterol determination in high-density lipoproteins separated by three different methods. Clin Chem 1977;23:882-4.

9. Goodman DS. New guidelines for lowering blood cholesterol and coronary risk. Atherosclerosis Rev 1988;18:75-84.

\title{
2uantitative Nephelometric Assay for Determining Myoglobin Evaluated
}

\author{
brls R. Delanghe, ' Jean-Paul Chapelle, ${ }^{2}$ and Serge C. Vanderschueren'
}

I recently introduced automated nephelometric immunoaslay involving shell/core particles for determination of myolobin (Behringwerke) was evaluated with the BNA Nephepmeter. Method precision was good: the intra-assay CV aried between $1.5 \%$ and $6.1 \%$; with daily calibration, the iterassay CV ranged between $1.5 \%$ and $7.5 \%$. For usual ample dilutions, the assay response varied linearly with hyoglobin concentrations up to $23.1 \mathrm{nmol} / \mathrm{L}$. After automatic flution by the instrument, concentrations up to $2310 \mathrm{nmol} / \mathrm{L}$ buld be measured without high-dose "hook" effect. Further panual dilution allowed measurement of myoglobin concenations up to $26000 \mathrm{nmol} / \mathrm{L}$. Calibration was stable for at ast seven days. We detected no significant interferences om hemoglobin, haptoglobin, bilirubin, iodine-containing ontrast media, and heumatoid factors. Treating lipemic

${ }^{1}$ Department of Clinical Chemistry, Universitair Ziekenhuis De intelaan 185, B-9000 Gent, Belgium.

2 Department of Clinical Chemistry, University of Liège, CHU35, Domaine Universitaire du Sart Tilman, B-4000 Liege, Belum.

Received April 6, 1990; accepted July 6, 1990. samples with Lipoclean (Behringwerke) decreased test results. Simultaneously drawn serum and plasma samples from the same subject showed no consistent differences in myoglobin 'concentrations. The mean reference myoglobin concentration was 1.380 (SD 0.82) $\mathrm{nmol} / \mathrm{L}$ for men and 0.878 (SD 0.45$) \mathrm{nmol} / \mathrm{L}$ for women. In patients with renal insufficiency, serum creatinine values were moderately related to serum myoglobin values $(r=0.465)$. Although a commercial radioimmunoassay (Byk-Sangtec) and the nephelometric assay intercorrelated well $(r=0.929)$, values obtained by nephelometry were significantly lower $(P<0.05)$. By both assays, results for heart and skeletal muscle tissue extracts showed no correlation, a finding that suggests the existence of multiple forms of myoglobin in human tissues. We conclude that immunonephelometry is a rapid, practical, and reliable method for measuring myoglobin in serum.

Additional Keyphrases: reference values - renal insufficiency · sex- and age-related effects

Myoglobin is a small-molecular-mass oxygen-binding protein $\left(M_{r} 17700\right)$, abundant in human skeletal and 
cardiac muscle. Determination of myoglobin concentrations in serum is therefore useful for evaluation of skeletal muscle damage (1), for early diagnosis and monitoring of acute myocardial infarction (AMI) (1-3), and for detecting coronary reperfusion (4) or reinfarction (1). Measuring cumulative myoglobin release in serum has been proposed for sizing infarcts (5).

In the routine clinical laboratory, myoglobin concentrations can be determined by radioimmunoassays (RIAs) (6) or by latex agglutination tests (7). However, RIAs are time consuming and therefore not suited for emergency testing. Latex agglutination tests give only semiquantitative results and can occasionally give false-negative results in the presence of antigen excess ("hook" effect). Because serum myoglobin concentrations in clinical practice are in the range 0.5-50 000 nmol/L, simultaneous serial serum dilutions must be measured. In the present study, we evaluated a recently introduced automated nephelometric method based on shell/core polymer particles coated with antimyoglobin antibodies and compared results with those obtained with a commercially available RIA. Here we present the results of this analytical evaluation, which was performed in two university hospitals.

\section{Materials and Methods}

Methods

Nephelometric method. In each center, myoglobin in serum, plasma, and tissue was assayed with an automated nephelometric immunoassay (NA-Latex Myoglobin Test; Behringwerke, Marburg, F.R.G.) based on shell/core particles coated with anti-myoglobin antibodies (8), with use of a selective multi-protein Behring Nephelometer Analyzer. In one center (A; Universitair Ziekenhuis, Gent), the analyzer had been intensively used for three years. The other center (B; Centre Hospitalier Universitaire, Liège) used a new analyzer. In both cases, the assay was performed according to the manufacturer's procedure, with a standard serum dilution of 1:20, unless otherwise stated, and a 12-min incubation time for the antigen-antibody reaction. We used a commercial myoglobin control serum from Behringwerke.

Comparison study. For comparison, we assayed myoglobin with an RIA (RIA-mat myoglobin no. 323.500 (3830); Byk-Sangtec, Dietzenbach, F.R.G.), performed according to the package insert. We assayed 127 serum samples (40 from healthy blood donors, six from renal insufficiency patients, 55 from acute myocardial infarction patients, 22 various samples with increased myoglobinemia, four control sera) and 29 tissue extracts, made from human heart ( $n=15)$ and skeletal muscle $(n=14)$ tissue samples obtained at autopsy. Tissue extracts were prepared according to Tsung (9).

Stability of the analyte. We evaluated the stability of the analyte in serum by measuring myoglobin concentration in various serum sample pools before and after storage at different temperatures: at room temperature (for two days), refrigerated $\left(4^{\circ} \mathrm{C}\right.$ for 10 days), and frozen $\left(-21^{\circ} \mathrm{C}\right.$ for 60 days).

Stability of calibration. To assess the stability of calibration of the nephelometric assay, we compared for each instrument the test results obtained with use of stored and daily calibration curves.

Imprecision. Nine different serum pools (P1-P9) were prepared from serum samples with increased myoglobin concentrations (>4.7 $\mathrm{nmol} / \mathrm{L})$. We tested intra-assay reproducibility with a series of 20 aliquoted samples from the different pools. We also pooled serum made from sample from patients with AMI, or with liver or renal insufficienc. Interassay reproducibility was evaluated by assaying 8 rum pools and the control serum during nine to 15 conser utive days.

Sensitivity and linearity. We tested the sensitivity of th nephelometric assay for serum in both standard and sixfol dilution, as provided by the instrument. To evaluate th linearity of the nephelometric assay, we used serial auth mated or manual dilution of serum samples from fiv patients with rhabdomyolysis, which contained high cor centrations of myoglobin in serum (575-28 $000 \mathrm{nmol} / \mathrm{L})$.

Interference studies. We studied the effects on myoglobi test results of adding to serum pools various potentiall interfering substances: purified human haptoglobin (phe notypes 1-1, 2-1, and 2-2, nos. H-0138, H-9887, and H-976: respectively; Sigma Chemical Co., St. Louis, MO 63178 and water-soluble iodine-containing roentgenographic cor trast media (Omnipaque; iodine content: 240 and $350 \mathrm{~g} / 1$ Nycomed, Oslo, Norway). Effects of triglycerides, hemogl bin, bilirubin, and rheumatoid factor were studied b adding to samples serum that was enriched in these corr pounds up to final concentrations of $13.7 \mathrm{mmol} / \mathrm{L}, 0.17$ $\mathrm{mmol} / \mathrm{L}, 547 \mu \mathrm{mol} / \mathrm{L}$, and 2500 int. units/L, respectively Lipid extraction of serum samples $(n=39)$ by means of th commercial extraction agent Lipoclean (Behringwerk was carried out according to the manufacturer's recommer dations (three volumes of extraction medium for two vo. umes of serum).

\section{Blood Samples}

Serum and EDTA- or citrate-treated plasma sample were centrifuged ( $1000 \times g, 10 \mathrm{~min}$, room temperature) an analyzed within $24 \mathrm{~h}$ after venipuncture.

\section{Patients}

Apparently healthy blood donors (197 men, mean age : SD: $39.9 \pm 13.0$ years, and 85 women, $39.8 \pm 12.1$ year served as a reference population for determining the nos $\mathrm{mal}$ range of myoglobin in serum. Serum samples from 9 patients with renal insufficiency (47 men, 44 women, aget $55.3 \pm 16.3$ years; serum creatinine and urea concentre tions of $875 \pm 424 \mu \mathrm{mol} / \mathrm{L}$ and $27.56 \pm 7.80 \mathrm{mmol} / \mathrm{I}$ respectively), were used to test the effect of glomerula filtration rate on the myoglobin concentration in serum.

\section{Results}

Reproducibility. Intra-assay coefficients of variation (CV) for patients' and control samples were between $1.5 \%$ an 6.1\%; daily calibrated interassay $\mathrm{CVs}$ were between 1.5 and 7.5\%. Lowest CV values were obtained with the ne equipment. Table 1 summarizes intra- and interassay CV for different pools used in the evaluation centers.

Sample stability. Storage of serum samples at roo temperature for $48 \mathrm{~h}$, refrigerated at $4^{\circ} \mathrm{C}$ up to one week, frozen during 60 days did not affect myoglobin valug significantly.

Stability of calibration. To compare the stability of dai and single calibration of myoglobin tests, we repeated measured serum pools and a control. Using a single cal bration curve during the entire period of interassay repr ducibility testing, we observed an increase in the impred sion in the two centers: in hospital A (pools 7-9), CV increased to $6.8-14.8 \%$ (vs 5.9-7.5\% with a new calibratid each day); in hospital B (pools 4-6), CVs increased 
Table 1. Reproduclbility of Nephelometric Myoglobin Determination

Center A

Intra-assay ( $n=20$ each)

\begin{tabular}{|c|c|c|c|}
\hline \multirow[b]{2}{*}{ Mean nmol/ } & \multirow{2}{*}{$\begin{array}{l}\mathrm{P} 1^{\circ} \\
6.64\end{array}$} & \multirow{2}{*}{$\begin{array}{l}\text { P2 } \\
6.13\end{array}$} & \multirow{2}{*}{$\begin{array}{l}\text { P3 } \\
6.05\end{array}$} \\
\hline & & & \\
\hline SD, nmollL & 0.41 & 0.13 & 0.16 \\
\hline CV, \% & 6.1 & 2.1 & 2.7 \\
\hline \multicolumn{4}{|c|}{ Interassay (with daily calibration) } \\
\hline & P7 & P8 & P9 \\
\hline No. of days & 9 & 9 & 9 \\
\hline Mean, nmol/L & 8.13 & 10.40 & 18.05 \\
\hline SD, nmol/L & 0.59 & 0.61 & 1.36 \\
\hline CV, \% & 7.2 & 5.9 & 7.5 \\
\hline \multicolumn{4}{|c|}{ Interassay (with single, stored calibration) } \\
\hline & P7 & P8 & P9 \\
\hline No. of days & 9 & 9 & 9 \\
\hline Mean, nmol/L & 7.34 & 10.07 & 15.98 \\
\hline SD, nmol/L & 0.74 & 0.68 & 2.41 \\
\hline CV, \% & 10.2 & 6.8 & 14.8 \\
\hline
\end{tabular}

- P1-P9: different serum pools; C, control serum.
Center B

$\begin{array}{cccc}\text { P4 } & \text { P5 } & \text { P6 } & \text { C } \\ 4.57 & 9.10 & 17.24 & 5.82 \\ 0.09 & 0.22 & 0.50 & 0.08 \\ 2.0 & 2.4 & 2.9 & 1.5 \\ & & & \\ \text { P4 } & P 5 & P 6 & C \\ 13 & 13 & 13 & 13 \\ 4.74 & 8.79 & 17.34 & 5.67 \\ 0.15 & 0.19 & 0.27 & 0.24 \\ 2.2 & 2.1 & 1.5 & 4.2 \\ & & & \\ \text { P4 } & \text { P5 } & P 6 & C \\ 15 & 15 & 15 & 15 \\ 5.07 & 9.16 & 17.66 & 6.11 \\ 0.25 & 0.38 & 0.88 & 0.33 \\ 4.8 & 4.2 & 5.0 & 5.4\end{array}$

4.2-5.0\% (vs 1.5-2.2\% with a new calibration each day). Table 1 summarizes results of calibration stability on various serum pools and controls.

Range and linearity. The basic measuring range covers myoglobin concentrations from 1.39 to $22.4 \mathrm{nmol} / \mathrm{L}$. When sample dilution was sixfold, concentrations as low as 0.34 $\mathrm{nmol} / \mathrm{L}$ could be detected. Samples with high myoglobin concentration can automatically be rerun by the analyzer by further sample dilution up to 1:100, 1:400, and 1:2000. In this way, we found the standard curve of the nephelometric method to be linear from 0.34 to about $2310 \mathrm{nmol} / \mathrm{L}$. A high-dose "hook" effect does not occur in the tested range (myoglobin concentrations up to $26000 \mathrm{nmol} / \mathrm{L}$ ).

Interferences. No interference from hemoglobin (up to a final concentration of $0.178 \mathrm{mmol} / \mathrm{L}$ ) and haptoglobin (up to a final concentration of $6.7 \mathrm{~g} / \mathrm{L}$ ) could be detected. Also, addition of solutions of the three different phenotypes (1-1, 2-1, and 2-2) of purified human haptoglobin (final concentration $0.5 \mathrm{~g} / \mathrm{L}$ ) to serum samples did not influence test results. Addition of bilirubin (final concentrations up to 547 $\mu \mathrm{mol} / \mathrm{L}$ ) and rheumatoid factor (final concentrations up to 2500 int. units $/ \mathrm{L}$ ) to serum pools with increased myoglobin concentrations did not interfere with the nephelometric assay. The presence of iodine-containing contrast media (Omnipaque) up to a final iodine concentration of $24 \mathrm{~g} / \mathrm{L}$ in the patients' sera did not interfere with the assay, except in pne out of 10 cases. However, the concentrations used exceed the maximal iodine concentrations usually obtained during coronarography $( \pm 15 \mathrm{~g} / \mathrm{L})$. Effects of hypertriglycpridemia on test results were negligible up to concentrajions of $13.7 \mathrm{mmol} / \mathrm{L}$.

Lipid extraction. Lipid extraction of normolipemic serum samples resulted in a variable relative loss $[23.3( \pm 20.5) \%$, median 38\%, $n=36$ ] of myoglobin concentration. In hyperipemic samples, loss of myoglobin concentration after lipid extraction was more pronounced [81.2 $( \pm 3.7) \%, \mathrm{n}=3]$. Addition to normolipemic serum of myoglobin-poor serum fich in triglycerides (final triglyceride concentration of 6.84 $\mathrm{mmol} / \mathrm{L}$ ) resulted in an increased myoglobin loss. Thereore, use of lipid extraction procedures before nephelometic determination of myoglobin is not recommended.
Comparison between serum and plasma test results. Myoglobin values in simultaneously drawn serum and EDTAplasma samples showed a good correlation: $y$ (EDTAplasma myoglobin, $\mathrm{nmol} / \mathrm{L}$ ) $=0.665 x$ (serum myoglobin, $\mathrm{nmol} / \mathrm{L})+1.757\left(r=0.956, \mathrm{n}=19, S_{y x}=2.89\right)$. However, for extremely low and high myoglobin concentrations, relative differences between serum and EDTA-plasma concentration may be high. Similar findings were obtained when serum was compared with citrate-treated plasma: $y$ (citrate-treated plasma myoglobin, $\mathrm{nmol} / \mathrm{L}$ ) $=1.18 x$ (serum myoglobin, $\mathrm{nmol} / \mathrm{L})+2.22\left(r=0.775, \mathrm{n}=10, S_{y x}=\right.$ 6.80).

Correlation with RIA-method. Myoglobin was simultaneously determined by both methods in a group of 127 serum samples from the reference population $(n=40)$, renal insufficiency $(n=6)$, and AMI patients $(n=55)$. A good correlation between the nephelometric and RIA assays for serum myoglobin was obtained: $\log [y$ (myoglobin-RIA, $\mathrm{nmol} / \mathrm{L})]=0.944 \log [x$ (myoglobin-nephelometry, $\mathrm{nmol} / \mathrm{L})]$ $+0.012\left(r=0.929, \mathrm{n}=127, S_{y x}=0.205\right)$. However, in both skeletal and heart muscle tissue samples, correlation between both methods was lacking.

Reference values. In the reference population, values for males $(1.35 \pm 0.81 \mathrm{nmol} / \mathrm{L})$ were significantly $(P<0.05)$ higher than those for females $(0.86 \pm 0.44 \mathrm{nmol} / \mathrm{L})$. In both

Table 2. Reference Values (Mean \pm SD) for Serum Myoglobin According to Age and Sex

\begin{tabular}{|c|c|c|c|c|}
\hline \multirow{2}{*}{$\begin{array}{c}\text { Age } \\
\text { group, y }\end{array}$} & \multicolumn{2}{|r|}{ Males } & \multicolumn{2}{|r|}{ Females } \\
\hline & $n$ & nmol/L & $n$ & nmoll \\
\hline $11-20$ & 4 & $1.297 \pm 0.105$ & 4 & $0.503 \pm 0.134^{a}$ \\
\hline $21-30$ & 39 & $1.162 \pm 0.531$ & 18 & $0.751 \pm 0.299^{b}$ \\
\hline $31-40$ & 80 & $1.325 \pm 0.804$ & 28 & $0.796 \pm 0.394^{b}$ \\
\hline $41-50$ & 42 & $1.440 \pm 0.852$ & 15 & $1.054 \pm 0.559^{a}$ \\
\hline $51-60$ & 17 & $1.436 \pm 0.649$ & 16 & $1.075 \pm 0.569^{n}$ \\
\hline $61-70$ & 15 & $2.046 \pm 1.497$ & 4 & $1.004 \pm 0.553^{a}$ \\
\hline
\end{tabular}

- $P<0.05,{ }^{b} P<0.01$. Differences between sex groups were evaluated by a Mann-Whitney $U$ test. 
sexes, reference values increased significantly with age. Table 2 depicts reference values for serum myoglobin concentration according to sex and age. Patients with renal insufficiency also showed significantly higher values. Values for serum myoglobin concentration in patients with various degrees of renal insufficiency are given in Table 3. In these patients, concentrations of serum creatinine and serum myoglobin correlated moderately: $y$ (myoglobin, $\mathrm{nmol} / \mathrm{L})=0.00587 x($ creatinine, $\mu \mathrm{mol} / \mathrm{L})+3.22(r=0.465$, $\left.\mathrm{n}=91, S_{y x}=6.314\right)$.

\section{Discussion}

The new nephelometric latex myoglobin test allows fast and convenient myoglobin determinations of high analytical quality, with use of only small amounts of serum (80 $\mu \mathrm{L})$. These properties make the method suited for delivering stat results. Intra- and interassay CVs are within acceptable limits. Assay results are available within 12 min, which makes the method suited for the emergency laboratory. Samples with high myoglobin concentration $(>23.1 \mathrm{nmol} / \mathrm{L})$ can be rerun automatically by the instrument from a higher predilution, which is an advantage with respect to RIA methods. Manual dilution of the serum sample was necessary in only one case, where serum myoglobin concentrations exceeded $139.5 \mathrm{nmol} / \mathrm{L}$. In the observed concentration range (0-26 $000 \mathrm{nmol} / \mathrm{L})$, no highdose "hook" effect could be detected, which is advantageous over latex agglutination tests, where false-negative results may be obtained owing to excess antigen (10). Daily calibration of the nephelometric assay resulted in lower interassay CV values. Calibration curves remained stable during at least one week. Reference values for serum myoglobin concentration obtained by nephelometry are lower than those obtained by RIA $(11,12)$. In agreement with literature, the reference values we obtained for serum myoglobin are age- and sex-related and positively correlated with serum creatinine concentration $(11,12)$. Interferences resulting from the presence of rheumatoid factors, hemoglobin, bilirubin, and triglycerides are negligible under routine conditions. Moreover, iodine-containing contrast media, often used in invasive procedures for evaluating and treating AMI, do not interfere with the nephelometric assay. Lipid extraction, which leads to an underestimation of the myoglobin concentration, is not recommended for turbid samples. With respect to Byk-

\begin{tabular}{|c|c|c|}
\hline & suffit & - \\
\hline $\begin{array}{l}\text { Serum creatinine } \\
\text { concn, umoll } \\
\text { (range) }\end{array}$ & $n$ & $\begin{array}{l}\text { Serum myoglobin } \\
\text { concn, nmoll:" } \\
\text { (mean } \pm \text { SD) }\end{array}$ \\
\hline $180-450$ & 20 & $3.75 \pm 1.45$ \\
\hline $450-700$ & 11 & $6.53 \pm 3.92$ \\
\hline $700-950$ & 17 & $7.80 \pm 4.62$ \\
\hline $950-1200$ & 19 & $9.99 \pm 6.65$ \\
\hline $1200-1500$ & 12 & $11.90 \pm 6.41$ \\
\hline$>1500$ & 12 & $11.73 \pm 6.53$ \\
\hline
\end{tabular}

Sangtec RIA results, good correlation was obtained for serum and plasma samples. However, values obtained bj the automated nephelometric assay are about 30\% lowes than those obtained by RIA.

In the tissue samples, a striking lack of correlatior between both assays was observed. These results may indicate differences between tissue and serum forms of myoglobin and demonstrate heterogeneity of antigenic sites of human myoglobin, which is in agreement witk earlier findings on human serum myoglobin (13) and ani. mal myoglobin $(14,15)$. Although the correlation betweer serum and plasma myoglobin concentrations was good important differences may be found at higher concentra. tions (increased values for citrate-treated plasma, de creased values for EDTA-plasma).

In conclusion, immunonephelometric determination 0 : serum myoglobin is a fast, convenient, and reliable method appropriate to the emergency laboratory.

We thank Mr. M. De Buyzere for his helpful discussions.

\section{References}

1. Kagen L. Myoglobin: methods and diagnostic uses. Crit Rer Lab Sci 1978;9:273-302.

2. Cairns J, Missirlis E, Walker W. Usefulness of serial determi. nations of myoglobin and creatine kinase in serum compared for assessment of acute myocardial infarction. Clin Chen 1983;29:469-73.

3. Chapelle J-P, El Allaf $M$, Larbuisson R, Limet $R$, Lamy $M$ Heusghem C. The value of serum CK-MB and myoglobin measure ments for assessing perioperative myocardial infarction after car diac surgery. Scand J Clin Lab Invest 1986;46:519-26.

4. Ellis A, Little T. Patterns of myoglobin release after reperfu. sion of injured myocardium. Circulation 1985;72:639-47.

5. Groth T, Hakman M, Hăllgren R, Roxin L-E, Venge P. Diag nosis, size estimation and prediction of acute myocardial infarctior from $S$-myoglobin observations. A system analysis to assess the influence of various sources of variability. Scand J Lab Invest 1980;40(Suppl 155):111-24.

6. Rosano T, Kenny M. A radioimmunoassay for human serum myoglobin: method development and normal values. Clin Cherr 1977;23:69-75.

7. Chapelle J-P, Heusghem C. Semi-quantitative estimation of serum myoglobin by a rapid latex agglutination method: ar emergency screening test for acute myocardial infarction. Clir Chim Acta 1985;145:143-50.

8. Kapmeyer W, Pauly H-E, Tuengler P. Automated nephelomet ric immunoassays with novel shell/core particles. J Clin Lab Ana 1988;2:76-83.

9. Tsung SW. Creatine kinase isoenzyme patterns in humar tissue obtained at surgery. Clin Chem 1976;22:173-5.

10. Toft E, Stentoft J, Andersen P. False-negative latex aggluti nation test for myoglobin owing to antigen excess [Letter]. Clir Chem 1988;34:177.

11. Hallgren R, Karlson F, Roxin L. Myoglobin turnover influena of renal and external factors. J Lab Clin Med 1978;91:246-54.

12. Chen I, David R, Maxon H, Sperling M, Stein E. Age-, sexand race-related differences in myoglobin concentrations in th serum of healthy persons. Clin Chem 1980;26:1864-8.

13. Van Rostenberghe $H$, Delanghe J, Wieme R. Glycosylation o human tissue myoglobin [Abstract]. J Clin Chem Clin Biochem 1988;26:334.

14. Wu J, Pieper R, Wu L, Peters J. Isolation and characterization of myoglobin and its two major isoforms from sheep heart. CliChem 1989;35:778-82.

15. Van Den Oord A. On the heterogeneity of equine myoglobin Protides Biol Fluids Proc Colloq 1969;17:267-77. 